\title{
Konflik dan rekonsiliasi antarjemaat: Sebuah analisis teologis
}

\author{
Johny Christian Ruhulessin \\ Fakultas Teologi, Universitas Kristen Indonesia Maluku, \\ chruhulessin@gmail.com
}

https://orcid.org/0000 0002-0088-8228

Keywords:

conflict; congregations; reconciliation; the protestant church of Maluku; theology of social; Gereja Protestan Maluku; jemaat; konflik;

rekonsiliasi; teologi sosial

\section{Article History}

Submitted: August 22, 2021

Revised: October 02, 2021

Accepted: October 07, 2021

DOI: https://doi.org/ 10.30995/kur.v7i2.362

Copyright: @2021, Authors.

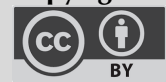

Scan this QR, Read Online

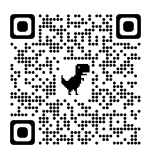

Abstract: Conflict and reconciliation are a reality in the life of congregations. Generally, conflict emerges in the life of the congregation because of nontheological reasons. Principally, congregations involved in a conflict have the responsibility to overcome the conflict. So do the Elpaputih and Samasuru, two congregations in the Protestant Church in the Moluccas involved in a conflict. This research aims to discover the potential reconciliation between these congregations. Through interviews and focus group discussions, the researcher discover that forgiveness is an essential bridge to reconciliation. At the end of the research, the author emphazise that reconciliation is a must because it is a church calling. For this case, the land as the source of the conflict must be a place for reconciliation when perceived as belonging to God and God's gift.

Abstrak: Konflik dan rekonsiliasi adalah kenyataan yang sangat sering dijumpai
dalam kehidupan berjemaat. Umumnya, konflik yang terjadi dalam kehidupan
jemaat didorong oleh faktor-faktor non-gerejawi. Pada hakikatnya, jemaat-
jemaat yang berkonflik itu memiliki tanggung jawab untuk menyelesaikannya.
Demikian juga dengan jemaat Samasuru dan jemaat Elpaputih; dua jemaat di
Gereja Protestan Maluku yang berkonflik. Oleh karena itu, penelitian ini bertu-
juan untuk menemukan potensi-potensi di dalam jemaat-jemaat ini untuk mem-
bangun rekosiliasi di antara mereka. Dengan melakukan wawancara dan focus
group discussion, penulis menemukan bahwa pengampunan merupakan jem-
batan menuju rekonsiliasi. Rekonsiliasi perlu dilakukan karena itu merupakan
panggilan jemaat, di mana tanah sebagai sumber konflik dapat menjadi tempat
rekonsiliasi, ketika tanah itu dilihat sebagai milik dan pemberian Tuhan.

Abstrak: Konflik dan rekonsiliasi adalah kenyataan yang sangat sering dijumpai dalam kehidupan berjemaat. Umumnya, konflik yang terjadi dalam kehidupan jemaat didorong oleh faktor-faktor non-gerejawi. Pada hakikatnya, jemaatjemaat yang berkonflik itu memiliki tanggung jawab untuk menyelesaikannya. Demikian juga dengan jemaat Samasuru dan jemaat Elpaputih; dua jemaat di Gereja Protestan Maluku yang berkonflik. Oleh karena itu, penelitian ini bertujuan untuk menemukan potensi-potensi di dalam jemaat-jemaat ini untuk membangun rekosiliasi di antara mereka. Dengan melakukan wawancara dan focus group discussion, penulis menemukan bahwa pengampunan merupakan jempanggilan jemaat, di mana tanah sebagai sumber konflk dapat menjadi tempat rekonsiliasi, ketika tanah itu dilihat sebagai milik dan pemberian Tuhan.

\section{Pendahuluan}

Maraknya persoalan kekerasan dan konflik yang terjadi dalam masyarakat menjadikan rekonsiliasi sebagai salah satu paradigma misi yang penting hingga saat ini. Rekonsiliasi sebagai model misi pada mulanya diusulkan oleh Robert Schreiter pada konferensi SEDOS tahun 1981.1 Rekonsiliasi menjadi fokus sentral dalam misi dan pelayanan gereja secara khusus sebagai kesaksian akan Kerajaan Allah. Di tengah-tengah konteks kekerasan yang didiamkan, rasa sakit yang tidak tertanggungkan, dan luka-luka pada memori manusia yang diakibatkannya, gereja sebagai instrumen Allah dalam proses rekonsiliasi mempersaksikan kabar baik mengenai damai sejahtera Allah melalui Kristus.

Stephen Bevans dan Roger Schoreder menglasifikasikan rekonsiliasi sebagai model misi dalam empat level yang berbeda. Level pertama adalah rekonsiliasi pada level personal. Pelaya-

${ }^{1}$ Stephen B. Bevans and Roger P. Schroeder, Constants in Context: A Theology of Mission for Today (Maryknoll, NY: Orbis Books, 2004), 390. 
nan rekonsiliasi pada level ini dapat dilakukan dengan mediasi, terapi kepada korban, dan pelayanan pastoral. Level kedua adalah rekonsiliasi pada level kultural. Kekerasan dan konflik dapat terjadi antara kelompok masyarakat ketika identitas kulturalnya tidak dihargai. Rekonsiliasi pada kasus-kasus tersebut dapat dilakukan dengan pelayanan melalui kehadiran gereja, serta memberi banyak waktu untuk mendengarkan dan mendapatan kepercayaan dari kelompok yang bertikai. Level ketiga adalah rekonsiliasi pada level politik. Contoh rekonsiliasi pada level ini adalah perdamaian nasional yang pernah diprakarsai oleh Nelson Mandela dan Desmon Tutu di Afrika Selatan. Level keempat adalah rekonsiliasi di dalam gereja. ${ }^{2}$

Gereja Protestan Maluku (selanjutnya ditulis GPM) adalah gereja pulau-pulau yang keberadaan jemaat-jemaatnya tersebar di Propinsi Maluku dan Maluku Utara, dengan keragaman budaya, bahasa dan adat istiadat. Secara geografis ada yang berada di pusat kota, pinggiran kota, sampai dengan pedalaman hutan dan puncak gunung. Dalam ketersebaran itu, pada umumnya, terbentuknya jemaat tidak bisa dilepas-pisahkan dari keberadaan negeri atau desa. Dalam realitasnya jemaat itu hadir secara geografis mengikuti pola kedudukan negeri (desa); di mana dapat dijumpai satu negeri adalah juga satu jemaat, tetapi ada juga satu jemaat yang terbentuk dari beberapa negeri. Jemaat dalam konteks GPM adalah basis pelayanan. Gereja terbentuk dari keberadaan jemaat-jemaat sebagai satu persekutuan tubuh Kristus yang saling membutuhkan dan saling melengkapi.

Kenyataannya sebagai satu persekutuan dalam konteks GPM yang saat ini memaknai diri dan panggilan sebagai sebuah persekutuan kerapkali diwarnai konflik antarjemaat. Beberapa data dan fakta konflik yang dapat diungkapkan mewarnai kehidupan dan menyita perhatian banyak kalangan adalah konflik Jemaat Porto-Haria. Di klasis Masohi, selain di Samasuru Elpaputih, juga terjadi konflik antara Makariki dan Sion; Sakela dan Yatfila; Isu, Watludan dan Jelestra.

Realitas konflik antarjemaat tentu menjadi sebuah kondisi yang ironi dalam persekutuan gereja sebagai satu keluarga Allah. Hal ini misalnya yang terjadi pada jemaat Samasuru dan jemaat Elpaputih di wilayah pelayanan klasis Gereja Protestan Maluku (GPM) Masohi. Kedua jemaat ini berada pada posisi yang saling berdampingan secara demografis. Lebih daripada itu, kedua jemaat ini memiliki tradisi dan budaya yang sama bahkan memiliki hubungan kekerabatan sebagai orang basudara. Konflik terjadi ketika pada tanggal 29 Desember 2008 ratusan perempuan jemaat Elpaputih memblokade ruas jalan trans-Seram dengan balok kayu. Aksi ini merupakan bentuk protes terhadap peletekan batu pertama tapal batas negeri tersebut. Situasi ini menyebabkan aparat keamanan dari Masohi datang unutk membongkar blokade hingga mengeluarkan tembakan dan melakukan aksi pemukulan terhadap warga setempat, dan sebagian besar masya-rakat lari ke hutan. Pada Maret 2016 terjadi konflik terbuka berupa kontak fisik antara pemuda Samasuru dan Elpaputih yang dipicu oleh pemasangan salib di sepanjang jalan transSeram oleh Jemaat Samasuru yang dianggap telah melewati batas negeri. Pada tanggal 4 Maret 2017 terjadi konflik terbuka yang mengakibatkan pengrusakan pemuki-man warga jemaat Samasuru oleh sebagian warga Elpaputih terkait dengan kegiatan Persidangan ke-33 Klasis GPM Masohi yang berlangsung di Samasuru. ${ }^{3}$

Peningkatan intensitas dan volume konflik antara jemaat Samasuru dan Elpaputih ini tidak bisa dilepaspisahkan dari peristiwa pelembagaan Jemaat GPM Samasuru yang lepas dari jemaat GPM Elpaputih pada tanggal 21 Oktober 2012. Walau demikian, benih konflik terkait dengan tapal batas dua negeri dan masalah pemerintahan yang terkait dengan konflik tapal batas Kabupaten Maluku Tengah dan Kabupaten Seram Bagian Barat, merupakan akar masalah di balik konflik antara kedua jemaat. ${ }^{4}$

Penelitian ini bertujuan untuk memberikan sebuah perspektif teologis mengenai konflik yang terjadi di dalam gereja, terutama antara jemaat. Gereja, sebagai satu persektuan tubuh Kristus dan keluarga Allah, tidak seharusnya terlibat di dalam konflik dan praktik kekerasan, me-

\footnotetext{
${ }^{2}$ Bevans and Schroeder, 392.

${ }^{3}$ Pdt. TK, Wawancara, 5 November 2020, Pukul 7.15.

${ }^{4}$ Pdt. ZH, Wawancara. 5 November 2020, Pukul 9.20
} 
lainkan seharusnya menjadi agen damai sejahtera Allah di tengah dunia. Kendati demikian, gereja sebagai sebuah entitas religius yang berada di tengah realitas sosial masyarakat, juga tidak dapat terhindar dari berbagai ancaman konflik, seperti yang terjadi antara jemaat Samasuru dan Elpaputih. Melalui penelitian ini, konflik antarjemaat dianalisis dengan analisis sosial-teologis yang dimulai dengan analisis mengenai realitas konflik, serta makna dan praksis rekonsiliasi dalam kehidupan gereja.

\section{Metode Penelitian}

Penelitian ini dilakukan menggunakan metode penelitian kualitatif untuk menggali makna utama di balik kenyataan konflik antarkedua jemaat, sekaligus mekonstruksi sebuah refleksi teologi sosial mengenai rekonsiliasi. Data mengenai konflik antarjemaat diperoleh melalui penelitian lapangan dengan mengobservasi dan mewawancari informa-informan kunci. Data itu kemudian dianalisis dengan pendekatan deskriptif-interpretatif untuk menemukan makna di balik kenyataan konflik dan upaya rekonsiliasi yang dibangun. ${ }^{5}$ Selanjutnya, kajian literatur digunakan untuk mendalami dinamika konflik, dan membangun refleksi teologi sosial mengenai konsep rekonsiliasi di dalam persekutuan gereja. Teologi sosial merupakan sebuah konstruksi reflektif yang memintal relasi antara teologi dan teori sosial, yang sering berbeda epistemiknya, tetapi secara dialektis dapat merambah suatu jalan bersama. Teologi itu sendiri tidak dibangun dari ruang hampa, tetapi di dalam realitas sosial, sehinggal korelasi keduanya secara dialektis menghasilkan refleksi teologi sosial. 6

\section{Hasil dan Pembahasan}

\section{Memaknai Konflik}

John Milbank menjelaskan bahwa kekerasan dan konflik disebut sebagai sebuah realitas sosial (sociality), sekaligus merupakan sebuah realitas teologis yang direfleksikan. ${ }^{7}$ Dalam sebuah realitas sosial, konflik antarmasyarakat merupakan sebuah kenyataan yang dapat memperkuat struktur hubungan-hubungan sosial. Oleh karena itu, konflik jangan hanya dilihat sebagai suatu masalah yang negatif (disfungsional) yang dapat merusak perdamaian, tetapi juga bersifat fungsional untuk kebaikan. Konflik dapat melahirkan pemikiran dan kesadaran keragaman yang lebih terbuka di dalam masyarakat. Dalam buku Dictionary of Pastoral Care and Counseling, konflik biasanya dianggap negatif, karena bertolak dari pengalaman yang dirasakan akibat konflik. Uraian ini mengakui kualitas negatif dari konflik yang terjadi dalam kehidupan manusia, tetapi juga mesti diakui bahwa konflik adalah sesuatu yang alami, tidak terhindarkan dari pusat keberadaan manusia. Namun, lewat konflik orang saling mengasihi dan menjadi lebih kreatif sehingga akhirnya orang bisa belajar untuk mengelola konflik dengan cara yang lebih konstruktif, sehingga konflik bukan membuat kehidupan menjadi tidak sehat dan terasing. ${ }^{8}$

Kenyataan konflik telah berlangsung sepanjang sejarah kehidupan manusia. Dalam Alkitab, ditemukan bahwa konflik juga terjadi dalam sejarah penciptaan manusia lewat antara Allah dengan Adam dan Hawa yang telah melanggar perintah Allah (Kej. 3: 12). Dalam kitab Kejadian dikisahkan tentang konflik yang terjadi di antara Kain dan Habel (Kej. 4:1-16) yang dipicu oleh kecemburan yang melahirkan kemarahan, dan berujung pada kekerasan dari Kain yang menghilangkan nyawa adiknya, Habel.

\footnotetext{
${ }^{5}$ Sugiyono, Metode Penelitian Dan Pengembangan (Research and Development/R\&D), Bandung: Alfabeta, 2016, https://doi.org/10.1016/j.drudis.2010.11.005.

${ }^{6}$ John Milbank, Theology and Social Theory: Beyond Secular Reason (Malden, MA: Blackwell Publishing, 2006), 4

7 Ibid., 6.

${ }^{8}$ Rodney J. Hunter, ed., Dictionary Pastoral Care and Counseling (Atlanta Georgia: Candler School of Theology Emory University,1998), 211.
} 
Dengan mengutip Dahrendorf, Demartoto menulis bahwa konflik berhubungan dengan kekuasaan dan kewenangan seseorang. ${ }^{9}$ Rantung mengutip Fisher dan Lucien yang menegaskan bahwa konflik yang mengkibatkan kekerasaan adalah berkaitan dengan proses mental, yakni perasan, sikap, dan nilai yang dianut dalam masyarakat. Konflik yang mengakibatkan kekerasan sebenarnya dapat dilihat sebagai suatu usaha individu atau kelompok yang memaksakan kehendaknya terhadap orang lain melalui cara-cara nonverbal, verbal, dan fisik. ${ }^{10}$ Dengan demikian dapat dilihat bahwa konflik yang berujung kekerasan yang dilakukan oleh Kain terhadap adiknya Habel menggambarkan keretakan relasi antar individu. Dalam kisah itu, persembahan Kain yang tidak diterima Allah membuatnya mengalami konflik diri dan luka batin. Ini adalah bagian dari sebuah konsekuensi psikologis dari pergulatan antara pikiran dan hati nurani. Menurut Caplan dan Lindemann sebagaimana yang dikutip Saragih, konflik diri didefiniskan sebagai keadaan kebingungan emosional seseorang atau unit sosial sehingga menghambat keseimbangan psikologis dan menjadikannya merasa cemas, malu, dan marah terhadap seluruh situasi dan orang terdekat. ${ }^{11}$

Pada umumnya, marah adalah salah satu sifat dasar yang dimiliki oleh setiap manusia. Dalam Alkitab pun dicatat bahwa Allah marah ketika umat kemudian berpaling dan menjadi tidak setia kepada-Nya. Seperti yang dikemukakan dalam Yehezkel 16: 43 bahwa "Oleh karena engkau tidak teringat lagi pada masa mudamu, tetapi dengan semuanya ini membuat Aku gemetar kemarahan, sungguh Aku akan menimpahkan, kelakuanmu atas kepalamu, demikianlah firman Tuhan Allah". Rene Girard yang dikutip oleh Emanuel Gerrith Singgih, menjelaskan salah satu faktor utama yang melahirkan konflik dan kekerasan dalam masyarakat yaitu, kemarahan yang tidak dikendalikan. Hal ini akan menjurus kepada berbagai tindakan kekerasan dan konflik yang dapat menimbulkan korban. 12

Menurut Halverstadt, paling kurang ada tiga makna penting yang berkaitan dengan pemahaman iman tentang penciptaan yang terkait dengan konflik dalam gereja (jemaat). Pertama, orang Kristen percaya bahwa dunia dan seluruh penghuninya diciptakan dengan baik, bukan buruk. Kedua, orang Kristen percaya bahwa manusia diciptakan menurut gambar Allah untuk menjadi penatalayanan bertanggung jawab atas seluruh ciptaan Allah yang baik itu. Ketiga, orang Kristen percaya bahwa manusia dirancang sebagai spesies yang saling tergantung, mahluk sosial. ${ }^{13}$ Bagi Halverstadt, karena manusia itu diciptakan Allah memiliki hak asasi yang penuh dengan nilai kemanusiaan, maka untuk alasan apapun hak itu tidak boleh direndahkan termasuk dalam situasi konflik. Oleh karena itu dengan segala akal dan kemampuan untuk berpikir, untuk bertindak, untuk berkomunikasi, untuk belajar maka secara hakiki manusia mampu memecahkan segala persoalan dan perbedaan-perbedaan melalui jalan-jalan yang lebih baik. Dalam prinsip sebagai makhluk sosial, perbedaan yang dimiliki ditempatkan dalam sebuah kesadaran akan saling ketergantungan satu terhadap yang lain. Perbedaan yang terdapat dalam setiap individu adalah perekat yang saling mengikat satu dengan yang lain bukan sebaliknya menimbulkan gesekan dalam hidup bersama. ${ }^{14}$

\section{Memaknai Rekonsiliasi}

Rekonsiliasi adalah sebuah istilah umum yang sering dipakai untuk menata kembali atau memperbaiki situasi di mana konflik sementara terjadi. Istilah rekonsiliasi berasal dari bahasa Latin, yaitu concilium, yang berarti mengandaikan suatu proses dengan sengaja, dan pihak-pihak yang berseteru, bertemu satu dengan membahas pandangan mereka yang berbeda dan mencapai kesepakatan bersama. ${ }^{15}$ Rekonsiliasi menjadi sesuatu yang sangat penting di tengah situasi konflik

${ }^{9}$ Argyo Demartoto, "Strukturalisme Konflik" dalam Jurnal Sosiologi: Dilema. Vol 24. No. 1 (2010), 4.

${ }^{10}$ Djoys Anneke Rantung, Resolusi Konflik dalam Organisasi, (Jakarta: BPK Gunung Mulia, 2017), 19 - 21.

${ }^{11}$ Mercy Anna Saragih, "Konflik Diri dan Konseling Pastoral Menuju Rekonsiliasi yang Mengutuhkan, dalam Teologi, Komunikasi dan Rekonsiliasi, Rudy Tindage dan Rainy Hutabarat, eds. (Jakarta, YAKOMA PGI, 2009$), 79$.

${ }^{12}$ Emanuel Gerrith Singgih, Korban dan Pendamaian, (Jakarta: BPK Gunung Mulia, 2018), 19.

${ }^{13}$ Hugh F. Halverstadt, Mengelola Konflik Gereja, (Jakarta: BPK Gunung Mulia, 2017), 35.

${ }^{14}$ Ibid., 36.

${ }^{15}$ Ibid., 125 
yang berkembang baik dalam masyarakat maupun dalam kehidupan gereja. Rekonsiliasi merupakan suatu usaha memulihkan keselarasan setelah masa konflik yang diawali dengan proses tindakan pengampunan atas tindakan masa lalu untuk memulai masa depan dalam sebuah kedamaian. 16

\section{Pengampunan: Jembatan Menuju Rekonsiliasi}

Rekonsiliasi dapat dipandang sebagai sebuah strategi untuk mengakhiri konflik. Ketika konflik terjadi dengan melibatkan aktvitas kekerasan yang telah saling menyakiti, maka salah satu jalan utama untuk berdama adalah pengampunan. Pengampunan dapat menjadi jembatan untuk hadirnya rekonsiliasi. Dalam proses rekonsiliasi, transformasi terjadi dalam kehidupan manusia, baik secara individu maupun persekutuan, sebagai akhir dari situasi konflik. Pada awal peciptaan manusia, sebagaimana diceritakan dalam kitab Kejadian, pengampunan Allah menjadi sebuah proses rekonsiliasi antara Adam dan Hawa setelah sebelumnya mereka saling mempersa-lahkan terhadap pelanggaran yang dibuat. Pengampunan Allah memungkinkan terjadinya transformasi kehidupan yang baru, kesempatan untuk hidup baru di luar taman Eden (Kej. 3:9-24).

Secara sederhana, pengampunan dapat diartikan sebagai sikap untuk tidak mengingat kembali, melupakan apa yang telah terjadi untuk memulai sesuatu yang baru. Sifat ini yang sering dijumpai dalam perjalanan sejarah kehidupan Israel, sebagai umat pilihan Allah. Ketika Israel berbuat yang jahat di mata Allah kemudian bertobat, maka Allah selalu mengampuni mereka, tidak lagi mengingat kesalahan mereka. Lewat pengampunan Allah menghadirkan pembaruan dan perubahan dalam kehidupan Israel.

Menurut Binsar Pakpahan, ingatan sangat kuat hubungannya dengan pengampunan dan rekonsiliasi dalam sebuah realitas konflik komunal. Dalam Nehemia 9 misalnya disimpulkan bagaimana Israel mengakui dan mengingat dosa-dosa mereka bahkan dosa para leluhur. Mereka mengingat bahwa Allah sudah menjadi Allah yang penuh anugerah, yang memelihara perjanjian dengan setia dan oleh karena itu Israel perlu pengampunan dari Allah. Ingatan akan dosa dan kesalahan masa lalu diperlukan agar mampu melangkah ke masa depan dengan pengampunan Allah. 17

Dalam pendekatan yang berbeda, teks Yeremia 34:31-34, Allah menyatakan pengampunan-Nya dengan tidak mengingat kesalahan dan dosa yang diperbuat oleh Israel. Sebuah perjanjian dan kehidupan baru diberikan Allah kepada Israel karena Allah mengampuni dengan tidak mengingat dosa-dosa mereka. Israel mengalami kehidupan baru yang membebaskan karena Allah memberikan anugerah dan pengampunan. Perjanjian dan kehidupan baru datang dan terjadi bagi Israel atas pengampunan dosa dan Allah tidak lagi mengingat dosa mereka ${ }^{18}$. Peristiwa yang lain juga dapat kita jumpai dalam Kejadian 33:1-20, di mana pengampunan yang dilakukan oleh Esau memulihkan hubungannya dengan Yakub saudaranya. Esau menjumpai Yakub menangis dan memeluknya dengan tidak mengingat lagi seluruh kesalahan dan penipuan yang Yakub lakukan. Dengan demikian dapat dipertegas bahwa sangatlah erat hubungan antara mengingat dengan pengampunan sehingga memungkinkan terjadinya rekonsiliasi sebagai akhir dari situasi konflik.

Rekonsiliasi antarjemaat juga merupakan suatu manifestasi dari nilai dan ajaran etika Kristen. Sejarah pertumbuhan dan perkembangan gereja, jemaat selalu bergumul tentang kehendak Allah dalam kehidupan dunia dan hasil pergumulan itu juga dijumpai dalam berbagai tulisan dan ucapan serta dokumen yang dikeluarkan oleh gereja untuk dipakai sebagai sumber dalam etika Kristen, walaupun dokumen dan tradisi tidak sama nilainya dengan Alkitab. ${ }^{19}$

Dalam Perjanjian Lama, ada satu prinsip etika yaitu Tuhan Allah menyatakan keesaaan diriNya dan menjadi Allah yang wajib dipercaya dan disembah bagi bangsa Israel. Keesaan Allah

\footnotetext{
${ }^{16}$ Ibid., 126.

${ }^{17}$ Binsar Pakpahan, Allah Mengingat: Teologi Ingatan sebagai Dasar Dalam Konflik Komunal, (Jakarta: BPK gunung Mulia, 2017), 152.

${ }^{18}$ Ibid., 154

${ }^{19}$ J. Verkuyl, Etika Kristen (Jakarta, BPK Gunung Mulia, 2016 ), 10
} 
berpengaruh pada ajaran etika yang disampaikan oleh Allah sendiri melalui firman-Nya sehingga menjadi keseragaman ajaran moral terhadap umat-Nya yang mesti ditaati oleh Israel tanpa pengecualian. Berbeda dengan bangsa yang lain, kesetiaan kepada Allah mesti diutamakan oleh Israel yang akan mendorong Israel menikmati sikap Allah yang penuh kasih setia (Kel. 20:3-6).20 Israel sebagai bangsa pilihan secara etis memiliki kewajiban berbeda dengan bangsa lainnya dalam kehidupan religiusitasnya, menyangkut soal ketaatan dan keteladanan terhadap ajaran Allah. Umat Israel tidak hanya dituntut untuk menanggapi tindakan Allah, tetapi juga wajib memperlihatkan sifat Allah melalui sikap dan perbuatannya di tengah keberadaannya bersama bangsa lain.

Salah satu pokok etika yang menarik dalam kitab Amsal adalah etika kehidupan sosial, dengan beberapa perkara sosial yang menjadi kekejian bagi Tuhan, antara lain: sombong, dusta, menumpahkan darah orang lain yang tidak bersalah, hati yang penuh rencana jahat dan menimbulkan pertengkaran dengan saudara (Ams. 6:16-19). Dengan demikian, yang ditegaskan dalam etika kehidupan sosial menurut Amsal adalah bersikap dan berbuat baik. Perkataan yang ramah itu suci, akan mengharmonisasikan hubungan dengan orang lain, jawaban yang lemah lembut meredekan kegeraman. Berbuatlah baik jika mampu melakukannya dan jangan merencanakan kejahatan terhadap sesamamu, jangan bertengkar sebab rancangan orang benar adalah berbuat adil (Ams. 15:1; 3:27, 12:5).21

Dalam Perjanjian Baru, penerapan sikap etik nampak dalam kasih Yesus yang mengampuni. Pengampunan yang terjadi lewat pengorbanan dan penderitaan di salib sebagai karya keselamatan dan penebusan atas dosa. Prinsip utama dalam ajaran etika Yesus adalah tentang kasih. Kasih terwujud dengan mengampuni sesama bukan hanya terbatas pada sahabat tetapi juga pada musuh dan alam semesta (Luk. 6:35). Pengampunan sebagai sikap etik harus nampak dalam hidup yang kasih, saling menghormati dan tidak saling menyakiti. Sikap mengampuni dan saling mengasihi akan mengharmonisasikan hubungan antar pribadi, antar jemaat, maupun umat dengan pelayan. ${ }^{22}$

\section{Rekonsiliasi Sebagai Panggilan Berjemaat}

Secara normatif, dalam persekutuan orang-orang percaya (jemaat), konflik itu semestinya tidak terjadi; namun, dalam realitasnya, konflik antarjemaat adalah sebuah fakta. Elpaputih dan Samasuru adalah dua Jemaat dalam persekutuan Gereja Protestan Maluku. Dua jemaat ini berkonflik karena persoalan batas tanah, sebab dua jemaat ini hidup saling berdampingan. Dalam situasi seperti ini tentu yang dibutuhkan adalah sebuah proses rekonsiliasi untuk memulihkan hubungan dan menghadirkan kedamaian dalam kehidupan bersama sebagai persekutuan tubuh Kristus.

Memang harus diakui, bahwa konflik dalam jemaat (gereja) atau konflik secara internal, di samping juga konflik-konflik eksternal, bukanlah sesuatu yang baru dalam sejarah perkembangan gereja. Sejarah terbentuknya gereja mula-mula di Asia kecil tidak bisa dilepaskan dari berbagai realitas konflik yang dialami. Konflik yang terjadi di jemaat Korintus misalnya, menjadi faktor utama untuk Paulus menuliskan suratnya kepada jemaat yang ada di sana. Perpecahan yang terjadi di dalam jemaat telah mengancam kesatuan sebagai persekutuan orang percaya yang berada di Korintus. Oleh karena itu dalam suratnya itu Paulus menaruh perhatian utama pada kesatuan dalam keragaman gereja dengan melihat pada aspek penting yaitu kesadaran akan identitas diri baik secara individu maupun kolektif sebagai suatu komunitas iman yang bertumbuh dari bayi menjadi dewasa dalam Kristus. Perpecahan dan pertengkaran yang terjadi dalam jemaat Korintus mesti ditarik dalam kesadaran bahwa jemaat adalah komunitas Kristen sebagai jemaat Allah (1Kor 1-4:21).

Dalam pandangannya, hal ini terlihat jelas, bahwa Paulus menempatkan diri dan jabatan kerasulannya bukan untuk memecah-belah tetapi untuk mengutuhkan kehidupan jemaat di Korintus. Dalam sisi ini, tentu memperlihatkan bahwa persoalan kepemimpinan (leadership)

\footnotetext{
${ }^{20}$ Karel Sosipater, Etika Perjanjian Lama, (Jakarta, Suara Harapan Bangsa, 2016), 40.

${ }^{21}$ Ibid., $397-398$.

22 Ibid., $502-503$
} 
menjadi salah satu pokok yang mengiring jemaat terjebak dalam perpecahan. Dengan demikian jawaban Paulus dalam suratnya sebagaimana yang tertulis dalam 1 Korintus 1:10-17, ingin mempertegas kedudukan sebagai seorang rasul atau pemimpin umat yang mesti berdiri dan berpihak kepada kebenaran yang mempersatukan umat, bukan sebaliknya membuat umat dalam keterpisahan dan perselisihan. Model dan karakter kepemimpinan pengembalaan yang ditunjukkan Paulus ini tentu menjadi kekuatan untuk meredam dan menyelesaikan konflik dan membangun rekonsiliasi di jemaat Korintus.

Pada sisi yang lain, studi Perjanjian Baru yang dilakukan oleh beberapa ahli telah mengalami perubahan dengan menyatakan bahwa persoalan konflik yang terjadi di jemaat Korintus tidak hanya menyangkut persoalan teologi tetapi juga mesti memperhatikan aspek-aspek lain seperti sosial-ekonomi. Petter Marshall dalam Malik mengatakan pendapatnya bahwa konflik jemaat Korintus juga menunjuk pada situasi sosial, diantaranya keragaman budaya, perbedaanperbedaan sosio-ekonomi anggota gereja (1 Kor. 1:26-29). ${ }^{23}$ Konflik di Korintus bukanlah sesuatu yang kebetulan tetapi berkaitan dengan hirarki sosial yang tajam dalam kota Korintus. ${ }^{24}$ Status sosial yang menjadi sumber persoalan jemaat di Korintus mesti dilihat sebagai sebuah fenomena multi dimensi yang mencakup kekuasaan, etnik, pendidikan, dan pekerjaan. ${ }^{25}$

Perpecahan atau pun konflik yang melanda persekutuan jemaat Elpapuith dan Samasuru, antargereja pada masa kini cendrung sama, yaitu dipengaruhi oleh situasi sosial politik, kekuasaan, budaya, ekonomi dll. Persekutuan jemaat yang telah terpecah dan terbelah mesti disatukan kembali supaya dapat hidup berdampingan secara damai dengan menunjukkan identitas dan jati diri sebagai tubuh Kristus. Rekonsiliasi sebagai tindakan Allah yang turun masuk ke dalam dunia untuk menyelamatkan dan membebaskan manusia dan semesta, perlu diwujudkan. Rekonsiliasi itu terjadi atas dasar inisiatif Allah untuk menghadirkan pembaruan situasi yang terjadi secara dialogis di mana Allah berprakarsa dan manusia memberi respon karena pendamaian itu tidak terjadi dalam ruang kosong.

Di dalam Perjanjian Baru, perdamaian (reconciliation), khususnya dalam surat-suratnya kepada jemaat di Roma dan Korintus, Paulus menggunakan kata kerja katallasso, yang terdapat dalam Roma 5:10; I Korintus 7:11; 2 Korintus 5:18-20. Menurut Marshall, sebagaimana yang dikutip oleh Yusak Tridarmanto, dikatakan bahwa satu-satunya alasan mengapa Paulus menggunakan konsep rekonsiliasi adalah untuk mempertajam dan menggarisbawahi konsep pembenaran. Oleh karena itu konsep tentang rekonsiliasi tidak terlalu memiliki peranan penting dalam keseluruhan teologi Paulus. Namun pendapat ini bertentangan dengan banyak penafsir yang menyatakan bahwa walaupun dari segi jumlah memang sangat terbatas, kurang lebih hanya sekitar enam kali, tetapi istilah rekonsiliasi benar-benar istilah yang sangat menentukan dan mempunyai makna begitu penting di dalam keseluruhan teologi Paulus. Katallasso dan kata bendanya, kattalage, memberikan gambaran teologis dan Kristologis atas diri Kristus dan pekerjaanNya secara lebih tepat dibandingkan dengan konsep-konsep sotereologi dalam Injil-Injil Sinoptis dan Kisah Para Rasul. Sotereologi merupakan pokok masalah besar dalam penulisan Rasul Paulus di mana konsep rekonsiliasi merupakan istilah kunci. Oleh karena itu, dalam upaya membahas makna rekonsiliasi dalam tulisan-tulisan Paulus, tidak bisa dilupakan perikop 2 Korintus 5:1821, karena di situlah Paulus secara jelas berbicara mengenai pokok masalah rekonsiliasi. ${ }^{26}$

Rekonsiliasi menjadi sesuatu yang penting dalam mengutuhkan kehidupan jemaat apa pun faktor yang mempengaruhi konflik itu, baik secara sosial politik, ethnik dan budaya. Rekonsiliasi yang Allah kerjakan mesti memberi dampak terhadap pemulihan hubungan antara manusia dan sesamanya. Rekonsiliasi dalam kehidupan jemaat Kristen sampai dengan masa kini adalah

\footnotetext{
${ }^{23}$ Debora K. Malik, Kesatuan dalam keragaman : Pendekatan Penggembalaan Paulus di Gereja Korintus dan Relevansi Untuk Gereja Masa Kini ( Jakarta : BPK Gunung Mulia, 2011), 23.

${ }^{24}$ Ibid., 26

${ }^{25}$ Ibid.. 29

${ }^{26}$ Yusak Tridarmanto, "Perdamaian dan Rekonsiliasi", dalam buku, Perempuan Konflik dan Rekonsiliasi, Perspektif Teologi dan Praksis, Basilica Dyah Putranti \& Asnath Niwa Natar, eds. (Jakarta: BPK Gunung Mulia, 2016), $14-15$.
} 
sesuatu yang tidak dapat ditawar dan digugat, sebab panggilan untuk berrekonsiliasi adalah sebuah bentuk respon kita terhadap karya keselamatan yang telah Allah kerjakan dalam diri Yesus Kristus. Jemaat yang tidak berrekonsiliasi adalah jemaat yang tidak meresponi karya keselamatan pendamaian yang dikerjakan Allah dalam diri Yesus Kristus.

\section{Rekonsiliasi Berbasis Hidup Orang Basudara}

Di Maluku sejak dulu sudah terkenal dengan tradisi kekerabatan dan hubungan persaudaraan yang menjadi perekat berbagai perbedaan suku, agama, bahasa dan budaya. Pela Gandong, Ain Ni Ain, Larvul Ngabal, Masohi27, adalah sebuah fakta sosial yang menjadi penanda tentang kuatnya hubungan kekerabatan dan persaudaraan di kalangan masyarakat Maluku yang telah menjadi warisan budaya dari para leluhur. Konflik sosial yang terjadi tahun 1999-2004 memiliki dampak yang besar terhadap keretakan hubungan dan ikatan kekeluargaan di Maluku. Banyak kalangan yang kemudian memikirkan kembali tradisi kekerabatan dan hubungan kekeluargaan di tengah kenyataan Maluku yang terus berkembang dan terbuka untuk menyelesaikan konflik.

Konsep orang basudara menunjuk realitas sosial masyarakat yang Maluku yang hidup secara damai dalam balutan tradisi kearifan lokal. Salah satu kearifan lokal dari jemaat Elpaputih dan Samasuru adalah dua jemaat ini hidup bertetangga dan memiliki ikatan persaudaraan yang disebut "mata rumah." Menurut Dieter Bartels, mata rumah berarti mata dari rumah, adalah marga atau fam garis keturunan tengah yang bersumber dari garis keturnan utama rumah tau/fam. Fungsi mata rumah adalah sebagai penanda bahwa kekerabatan yang terbangun di masyarakat secara kultural terjadi menurut garis keturunan. ${ }^{28}$ Pada jemaat Elpaputi dan Samasuru, terdapat garis keturuan yang sekalipun hidup terspisah pada setiap jemaat, tetapi terikat dalam garis mata rumah. Pada ikatan itulah, kedua jemaat ini dihidupi oleh orang-orang yang mempunya ikatan kekeluargaan mata rumah. Jadi, kedua jemaat ini adalag bersaudara dalam ikatan budaya.

Dalam konteks bergereja, kedua jemaat ini adalah bagian dari persekutuan bersama dalam Gereja Protestan Maluku (GPM). Keberadaan kedua jemaat merupakan manivestasi dari tubuh Kristus. Dalam eklesiologi GPM, jemaat-jemaat dipahami sebagai sebuah persekutuan "Keluarga Allah". Jemaat (gereja) orang basudara baik secara eksternal maupun internal adalah perwujudan ikatan persaudaraan yang berlandaskan relasi antara Allah dalam Yesus Kristus sebagai Kepala Gereja baik antarjemaat maupun antarsesama dan alam semesta. Memaknai ikatan jemaat sebagai satu keluarga Allah merupakan aktualisasi dari ajaran Yesus, yang diarusutamakan dalam kesaksian penulis Perjanjian Baru. ${ }^{29}$ Jadi, baik dalam perspektif teologis maupun perspektif budaya orang basudara, rekonsiliasi bukan lagi sebuah pilihan bagi persekutuan jemaat, melainkan sebuah imperatif iman secara teologis sekaligus imperatif virtue kultural.

\section{KESIMPULAN}

Jemaat Elpaputih dan Samasuru yang adalah cerminan dari persekutuan tubuh Kristus yang sementara terkoyak akibat konflik. Konflik yang terjadi dalam kehidupan kedua jemaat ini dalam waktu lama ini perlu dibangun sebuah jalan pengampunan untuk menuju proses rekonsiliasi. Kesalahan dan tindakan yang terjadi masa lalu perlu direfleksikan sebagai sebuah manifestasi kesalahan bersama, yang memerlukan pengampunan dari Allah, dan teraktualisasi dalam persekutuan yang saling mengampuni. Rekonsiliasi antara kedua jemaat merupakan sebuah panggilan menghadirkan misi Allah yang mewujunyatakan syalom di tengah dunia. Di dalam perspektif budaya, kedua jemaat ini terikat di dalam kultur mata rumah yang mempertegas bahwa mereka adalah bersaudara. Dengan demikian, rekonsiliasi antara kedua jemaat Elpaputih

\footnotetext{
${ }^{27}$ Pela Gandong, Ain Ni Ain, Larvul Ngabal, Masohi adalah konstruksi budaya yang menggambarkan hubungan kekeluargaan, ikatan-ikatan persaudaraan melintasi batas suku, budaya dan agama.

${ }^{28}$ Dieters Bartels, Di bawah naungan Nunusaku, Muslim - Kristen hidup berdampingan di Maluku Tengah, (Jakarta: KPG 2017 ), $192-193$.

${ }^{29}$ Yohanes Parihala, "Menggali makna keluarga Allah dalam dunia Alkitab dan surat Efesus: analisis historisbiblis." KURIOS (Jurnal Teologi dan Pendidikan Agama Kristen) 7, no. 1 (2021): 149-163.
} 
dan Samasuru selain sebagai sebuah impertaif teologis, juga merupakan imperative kultural. Dalam konteks inilah, teologi rekonsiliasi merupakan sebuah teologi kontekstual, yang dapat merespon persoalan konteks konflikantar jemaat.

\section{REFERENSI}

Bartels Dieters, Di bawah naungan Nunusaku, Muslim - Kristen hidup berdampingan di Maluku Tengah. Jakarta: KPG 2017.

Bevans, Stephen B., and Roger P. Schroeder. Constants in Context: A Theology of Mission for Today. Maryknoll, NY: Orbis Books, 2004.

Demartoto Argyo. Strukturalisme Konflik: Pemahaman akan konflik pada masyarakat Industri menurut Lewis Coser dan Ralf Dahrendorf. Dalam Jurnal Sosiologi: Dilema. Vol.4. No.1 (2010). Universitas Sebelas Maret.

Halverstadt Hugh F. Mengelola Konflik Gereja. Jakarta, BPK Gunung Mulia, 2017.

Hunter Rodney J., ed. Dictionary Pastoral Care and Counseling Atlanta Georgia. Candler School of Theology Emory University, 1998.

Karman Yongky. Bunga Rampai Teologi Perjanjian Lama. Jakarta : BPK Gunung Mulia, 2007.

Malik Debora K. Kesatuan dalam keragaman: Pendekatan Penggembalaan Paulus di Gereja Korintus dan Relevansi untuk Gereja Masa Kini. Jakarta: BPK Gunung Mulia, 2011.

Milbank, John. Theology and Social Theory: BEyound Secular Reason. Malden, MA: Blackwell Publishing, 2006.

Pakpahan Binsar. Allah Mengingat: Teologi Ingatan sebagai Dasar Dalam Konflik Komunal. Jakarta: BPK gunung Mulia, 2017.

Parihala, Yohanes. "Menggali makna keluarga Allah dalam dunia Alkitab dan surat Efesus: analisis historis-biblis." KURIOS (Jurnal Teologi dan Pendidikan Agama Kristen) 7, no. 1 (2021): 149-163.

Rahmadani Deshi T. A., Menciptakan Langit Dan Bumi Baru Sebagai Tubuh Baru Allah, dalam buku, Iman yang Merangkul Bumi, Peter C. Aman, editor. Jakarta: Obor, 2014.

Rantung Djoys Anneke. Resolusi Konflik Dalam Organisasi. Jakarta: BPK gunung Mulia, 2017.

Saragih Mercy Anna. "Konflik diri dan konseling pastoral menuju rekonsiliasi yang mengutuhkan", dalam Teologi, Komunikasi dan Rekonsiliasi, Rudy Tindage dan Rainy Hutabarat, eds. Jakarta, YAKOMA PGI, 2009.

Singgih Emanuel Gerrith. Korban dan Pendamaian. Jakarta, Penerbit: BPK Gunung Mulia, 2018.

Sosipater Karel. Etika Perjanjian Lama. Jakarta, Suara Harapan Bangsa, 2016.

Tridarmanto Yusak. "Perdamaian dan Rekonsiliasi", dalam Perempuan Konflik dan Rekonsiliasi, Perspektif Teologi dan Praksis. Basilica Dyah Putranti \& Asnath Niwa Natar, eds. Jakarta: BPK Gunung Mulia, 2016.

Sugiyono. Metode Penelitian Dan Pengembangan (Research and Development/R\&D). Bandung: Alfabeta, 2016. https://doi.org/10.1016/j.drudis.2010.11.005.

Verkuyl J. Etika Kristen. Jakarta: BPK Gunung Mulia, 2016.

Watloly Aholiab. Cermin eksistensi Masyarakat kepulauan dalam pembangunan Bangsa. Jakarta: PT Intimedia Cipta Nusantara 2013.

Wright Christopher. Hidup Sebagai Umat Allah: Etika Perjanjian Lama. Jakarta: BPK Gunung Mulia,1995.

Yewangoe A.A. "Gereja di Era Reformasi", dalam Gereja dan Reformasi: Pembaruan Gereja Menuju Indonesia Baru. Victor Silaen, ed. Jakarta: Yakoma PGI, 1999. 